\title{
THE INHERITANCE OF VARIEGATED FLOWER COLOUR IN DELPHINIUM AJACIS
}

\author{
G. W. P. DAWSON \\ School of Botany, Trinity College, Dublin
}

Received 19.iv.55

Some years ago Dr D. G. Catcheside kindly supplied me with seeds of a strain of Delphinium ajacis. The strain includes plants that differ in the colour of their sepals. In some plants the sepals are pink, in others the pink is spotted, streaked and sectored with blue, and occasionally on such plants wholly blue flowers or, even more occasionally, wholly blue inflorescences are found. These variegated plants have sectors of the sepals, or occasionally whole flowers or inflorescences, that are pink, without any blue spots or streaks. These plants are similar in appearance to those described by Sirks (1950). The presence of pink sectors in the variegated flowers distinguishes the strain from that described by Demerec (I93I). The difference between a plant with pink flowers and one with variegated flowers may, not unreasonably, be attributed to a stable gene $(p)$ for pink pigment in one and a similar but unstable gene $\left(p^{*}\right)$ that could mutate to either the stable allele $(p)$ or to an allele $\left(p^{b}\right)$, that gives rise to the production of a blue pigment, in the other.

The numbers of pink and variegated pink offspring obtained when a variegated pink plant was crossed with a pink plant and when it was self pollinated were :-

\begin{tabular}{|c|c|c|c|c|}
\hline & $\begin{array}{l}\text { Variegated } \\
\text { pink }\end{array}$ & Pink & Blue & Total \\
\hline Variegated pink $\times$ pink & 73 & 108 & I & 182 \\
\hline Pink $\times$ variegated pink & хо6 & 210 & I & $3 \times 7$ \\
\hline Variegated pink $\oplus$ & 59 & 37 & 3 & 99 \\
\hline
\end{tabular}

If we assume that the genotype of the variegated pink parent was $p^{*} p$ and that of the pink parent was $p p$ we must conclude that the data show significant deviations from the expected classical mendelian ratios. It is, however, interesting to note the agreement between the backcross data and the selfing data. If we calculate the proportions of effective embryo sacs with $p^{*}, p$ and $p^{b}$ genes in the unstable pink parent from the first backcross and the corresponding proportions of effective pollen grains from the second backcross, it is then possible 
to calculate the expected numbers of the different types of offspring from the selfing.

\begin{tabular}{|r|c|c|c|c|}
\hline & $\begin{array}{c}\text { Variegated } \\
\text { pink }\end{array}$ & Pink & Blue & Total \\
\hline Variegated pink $\oplus$-Obs. & 59 & 37 & 3 & 99 \\
Exp. & $59 \cdot 23$ & $38 \cdot 92$ & 0.85 & 99 \\
\hline
\end{tabular}

It was shown that $p^{*}$ mutates to $p^{b}$ in the germ line by pollinating a pink plant with pollen from a wholly blue flower of a variegated plant.

\begin{tabular}{|c|c|c|c|c|}
\hline & $\begin{array}{c}\text { Variegated } \\
\text { pink }\end{array}$ & Pink & Blue & Total \\
\hline $\begin{array}{c}\text { Pink } \times \text { blue flower of variegated } \\
\text { pink }\end{array}$ & 36 & 164 & 52 & 252 \\
\hline
\end{tabular}

The large proportion of offspring with blue flowers indicates that many of the pollen grains arose from the same mutant tissue from which the blue sepals developed. The effective ratio of $p^{*}$ and $p^{b}$ to $p$ pollen grains $\left(88:{ }_{1} 64\right)$ is almost identical to that of the similar cross using pollen from a variegated flower (107:210).

Similarly when a pink plant was pollinated with pollen from a wholly pink flower of a variegated plant, there is an excess of pink plants among the offspring.

\begin{tabular}{|l|c|c|c|c|}
\hline & $\begin{array}{c}\text { Variegated } \\
\text { pink }\end{array}$ & Pink & Blue & Total \\
\hline $\begin{array}{c}\text { Pink } \times \text { pink flower of variegated } \\
\text { pink }\end{array}$ & 49 & 136 & 5 & $\mathbf{1 9 0}$ \\
Cf. pink $\times$ variegated pink & 106 & 210 & I & $\mathbf{3} \times 7$ \\
\hline
\end{tabular}

Thus it would appear that $p^{*}$ mutates to $p$ and to $p^{b}$ in the germ line as well as in the somatic tissues of the sepals. Further it would appear that the germ line is not a distinct line of cells but may be derived, at least in part, from the same tissue that gives rise to the sepals. As would be expected one occasionally finds flowers with wholly blue sepals that do not have a high proportion of $p^{b}$ pollen grains and conversely variegated flowers that do have a high proportion of $p^{b}$ pollen grains-results that can be interpreted in terms of the spatial limits of the $p^{b}$ mutant tissue. 
If the blue mutant plants among the offspring of the pink $\times$ blue flower of variegated pink cross are the result of mutations of $p^{*}$ to $p^{b}$ then they should have the genotype $p^{b} p$. Seven such blue plants were self pollinated and the offspring consisted of 53 blue and 12 pink plants, which is in good agreement with the expected $3:$ I ratio. The absence of any variegated pink offspring supports the theory that the variegation is due to an unstable allele of pink that itself mutates to an allele which determines the formation of blue pigment, rather than being due to a gene at another locus that determines the high mutation of the $p$ gene.

All the data so far quoted are derived from crosses involving only two plants-one pink and the other bearing mainly variegated but also some wholly pink and some wholly blue flowers. Similar crosses involving other plants have confirmed these results ; the only variation being in the degree of departure from the expected classical mendelian ratios.

These breeding data are very different from those of Sirks (1950). His data led him to assume that his variegated pink plants were permanent heterozygotes and the variegation due to somatic segregation. In particular he found no variegated pink plants which bred true. The theory based on the present data leads one to expect variegated pink plants, $p^{*} p^{*}$, which breed true except for the occasional blue mutant and the even more occasional self pink mutant. Such plants have been found. It is clear that the strain studied here is different genetically from that of Sirks.

Other plants of this strain have lavender sepals which are spotted, streaked and sectored with blue. Some of these plants were crossed with pink and of the 116 offspring 62 were pink variegated with blue, 48 were lavender and 6 were pink. The interesting feature being the complete absence of any variegated lavender plants. Thus we may tentatively assume that lavender is an allele of $p$ and we can symbolise it by $p^{l}$. The variegated lavender plants would thus have the genotype $p^{*} p^{l}$, the $p^{b}$ tissue formed by the mutation of $p^{*}$ showing through the lavender of the sepals as blue spots and sectors. While admitting that one may be studying closely linked loci, at present there is no evidence to show that the four genes, $p, p^{*}, p^{b}, p^{l}$ are not alleles. Their dominance relationships can be expressed in the following way :-

$$
p^{b}>p_{p^{l}}^{*}>p
$$

Another type of variegated flower is one which has pink sepals which are marked with rose. These markings range from what can best be described as a mottling, to distinct streaks and sectors. It may be that these markings are to be interpreted in terms of an unstable gene, but if so, there is no evidence that it mutates in the germ cells. At present it may be regarded as a simple character 
determined by a recessive gene $(m)$. This is illustrated by the following data-all the pink parent plants are heterozygous for mottled $(\mathbf{M m})$.

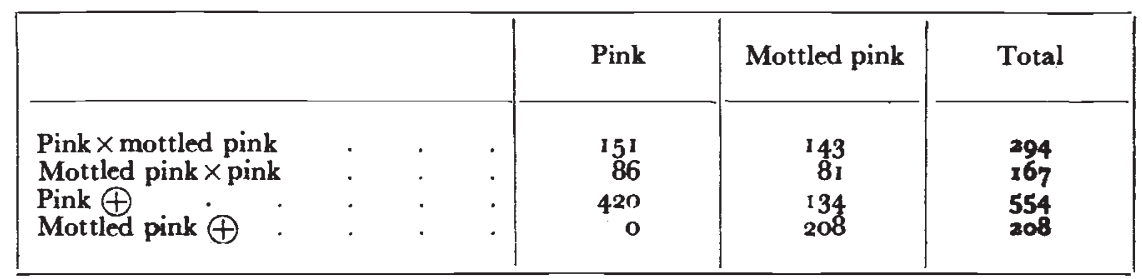

The data clearly demonstrate the simple mendelian inheritance of the mottled character.

To test whether the $p$ and $m$ were closely linked, plants of genotype $p^{*} p M m$ were self pollinated and crossed with plants of genotype ppmm. The mottled character is usually distinguishable on a blue background as purplish markings.

\begin{tabular}{|l|c|c|c|c|c|c|c|}
\hline & $\begin{array}{c}\text { Variegated } \\
\text { pink }\end{array}$ & Pink & $\begin{array}{c}\text { Variegated } \\
\text { pink } \\
\text { mottled }\end{array}$ & $\begin{array}{c}\text { Pink } \\
\text { mottled }\end{array}$ & Blue & $\begin{array}{c}\text { Blue } \\
\text { mottled }\end{array}$ & Total \\
\hline$p^{*} p M m \times p p m m$ & 33 & 31 & 34 & 36 & 1 & 0 & $\times 35$ \\
$p p m m \times p^{*} p M m$ & 23 & 28 & 21 & 32 & 0 & 1 & 105 \\
$p^{*} p M m \oplus$ & 33 & 11 & 11 & 2 & 0 & 1 & $5^{8}$ \\
\hline
\end{tabular}

The good bifactorial ratios indicate the absence of close linkage between the $p$ and $m$ loci. In these crosses the deficiency of variegated pink plants appears to be much less than in the previously described crosses involving this character.

\section{SUMMARY}

1. The genetics of a strain of Delphinium ajacis with variegated flowers has been investigated. The breeding data suggest that there is an unstable gene for pink flower colour that mutates to a stable gene for pink flower colour and to a stable gene for blue flower colour. These mutations occur in the developing sepals and in the cells that give rise to the embryo sacs and pollen grains.

2. Further data indicate the presence of a recessive gene for mottled pink flowers that is not linked to the unstable gene for pink flower colour.

\section{REFERENCES}

DEMEREc, м. I93і. Behaviour of two mutable genes of Delphinium ajacis. 7 . Genet. 24, I 79 .

SIRKS, M. J. 1950. Sobre los genes "inestables". Genetica Iberica, 2, rog. 